DOI: $10.12797 /$ Politeja.12.2015.36.16

\title{
Tadeusz WALLAS
}

Uniwersytet im. Adama Mickiewicza w Poznaniu

tadeusz.wallas@gmail.com

\section{PRZYCZYNEK DO ROZWAŻAŃ NAD PRZYNALEŻNOŚCIĄ DZIEDZINOWĄ NAUK O POLITYCE}

ABSTRACT Contribution to the considerations on the assignment of political sciences to a scientific field

Since the number of academic specializations and disciplines has consistently been increasing, it has become necessary to supplement present classifications and categorizations, as well as come up with new ones, on a regular basis. Therefore, it has become feasible to distinguish a new branch of science as well as to assign the existing disciplines to different branches. It is owing to such a process that political sciences have been reassigned in Poland. Before September 30, 2011, political sciences had been categorized as the humanities, but later on they were encompassed by a new branch of social sciences, created as a result of the division of the humanities. I adopt the thesis that this decision was substantially justified since, given current legal status quo, political sciences as a discipline have more in common with other disciplines assigned to social sciences than the humanities. Additionally, by way of developing a new register of disciplines, the administrative divisions in Polish science were to a large extent aligned with the classification of branches and disciplines adopted by the OECD, UNESCO and Eurostat, which will facilitate the internationalization of academic collaboration. The above organizations and institutions, and - consequently - some of their member states, have already divided the humanities, sometimes also named social sciences, into two separate branches: social sciences and humanities. In order to justify the above-mentioned thesis it was necessary to determine how academic specialization, discipline, branch and field of science are perceived today; to indicate the determinants of divisions in science and basic criteria for such divisions; to attempt to define the specific nature of the humanities versus social 
sciences; and to present the factors confirming the relation of political science to the latter category.

Słowa kluczowe: nauki o polityce, nauki społeczne, nauki humanistyczne, dziedzinowa przynależność nauk o polityce, klasyfikacja nauk

Keywords: political sciences, social sciences, humanities, categorization of political sciences as a branch of science, classification of sciences

$\mathrm{R}$ ozwój wiedzy naukowej pozwalał już starożytnym filozofom dostrzegać zróżnicowanie nauki. $Z$ niejednorodności wiedzy filozoficznej zdawał sobie sprawę już Platon. Jednak bardziej rozwinięty podział takiej wiedzy zaproponował Arystoteles, który zauważył, iż rodzaj nie istnieje w żadnym razie bez gatunków rodzaju ${ }^{1}$. Kierując się celem postępowania badawczego $i$ stopniem wyabstrahowania (od materii) jejprzedmiotu, dokonał on interesującego, jak na stan ówczesnej wiedzy, podziału nauk ${ }^{2}$ na teoretyczne, praktyczne i pojetyczne, tj. wytwórcze. Celem tych pierwszych, najważniejszych zdaniem tego autora, była troska o poznanie prawdy dla niej samej, która umożliwi określenie zasad poznania świata. Zadaniem drugich nauk było określenie zasad działania świata, a przede wszystkim tego, co dobre, w tym działaniu. Za nauki praktyczne Arystoteles uznał - co interesujące dla naszych rozważań - etykę i politykę. Natomiast zadaniem nauk wytwórczych było ustalenie zasad wytwarzania rzeczy pięknych lub użytecznych. Przedstawiony podział, chociaż bardzo ogólnikowy, to jednak wywarł duży wpływ na próby klasyfikacji nauk w kolejnych stuleciach. Zasługą starożytnych filozofów było przede wszystkim uświadomienie kolejnym pokoleniom badaczy, jeśli powołamy się na zdecydowanie później wypowiedziane słowa Kartezjusza, że nauka przypomina drzewo z korzeniami i pniem, z którego wyrastają konary, a z nich gałęzie ${ }^{3}$.

Dziewiętnastowieczne przyspieszenie w znoszeniu feudalnych ograniczeń, dostrzeżenie korzyści gospodarczych i cywilizacyjnych z efektów pracy naukowców i zespołów badawczych, objęcie ośrodków prowadzących badania mecenatem państwa, a także wzrost liczby takich ośrodków i osób w nich pracujących umożliwiły intensyfikację badań naukowych. Spowodowało to przyspieszenie wzrostu liczby specjalności i dyscyplin naukowych. Ponieważ proces ten systematycznie postępuje, koniecznością staje się częste uzupełnianie dotychczasowych klasyfikacji i systematyzacji, a także tworzenie nowych. W takiej sytuacji możliwe jest wyodrębnianie nowych dyscyplin naukowych

Cyt. za: A. Marcos, Filozofia nauki. Nowe wymiary, przeł. i red. P. Roszak, Toruń 2012, s. 137.

2 Nauki w znaczeniu nadanym temu słowu przez Arystotelesa to raczej „dziedziny wiedzy filozoficznej”. Zob. szerzej: G. Reale, Historia filozofii starożytnej, t. 2: Platon i Arystoteles, przeł. E.I. Zieliński, Lublin 2001, s. 367.

3 S. Kamiński, Pojęcie nauki i klasyfikacja nauk, wyd. 3 uzup., Lublin 1981, s. 234-239, Rozprawy Wydziatu Filozoficznego Towarzystwa Naukowego Katolickiego Uniwersytetu Lubelskiego, 35. Szerzej na temat dawnych podziałów w nauce: tamże, s. 41, 234-244. 
i dziedzin nauki lub dzielenie istniejących, a także nowe dziedzinowe przyporządkowanie dyscyplin. Właśnie w rezultacie takiego procesu zmieniła się przynależność nauk o polityce w Polsce. Do 30 września 2011 r. dyscyplina ta zaliczana była do dziedziny nauk humanistycznych, a po tej dacie włączono ją do nowej dziedziny nauk społecznych, która powstała przede wszystkim w wyniku podziału humanistyki ${ }^{4}$. W związku z tym przyjmuję tezę, zgodnie z którą taka decyzja była uzasadniona merytorycznie, ponieważ dyscyplina nauki o polityce, przy obecnym stanie prawnym, w porównaniu z dyscyplinami nauk humanistycznych ma więcej cech wspólnych z innymi dyscyplinami zaliczonymi do dziedziny nauk społecznych. Ponadto, poprzez ustalenie nowego wykazu dziedzin i dyscyplin administracyjne podziały w polskiej nauce zostały w znacznym stopniu dostosowane do klasyfikacji wypracowanych na forum OECD, UNESCO i Eurostatu, co ułatwi internacjonalizację współpracy naukowej. Na forach tych organizacji i instytucji, a co za tym idzie także w wielu ich państwach członkowskich już wcześniej podzielono nauki humanistyczne - kiedyś zamiennie nazywane naukami społecznymi - na dwie dziedziny: nauk społecznych i nauk humanistycznych. W celu potwierdzenia słuszności tego twierdzenia konieczne będzie: ustalenie współczesnego pojmowania istoty specjalności naukowej, dyscypliny naukowej, dziedziny nauk i obszaru wiedzy naukowej; wskazanie najważniejszych determinantów podziałów w nauce i ich podstawowych kryteriów; podjęcie próby określenia specyfiki nauk humanistycznych oraz nauk społecznych, a także ukazanie czynników świadczących o związkach politologii z tą ostatnią dziedziną nauk.

Dla należytej oceny podziałów w nauce konieczne staje się określenie jednostek umożliwiających ich przeprowadzanie. W tej sprawie występuje względna zgodność poglądów. Najmniejszą jednostką podziału jest specjalność naukowa (badawcza). Andrzej Chodubski uważa, że wyróżnia ją ściśle określony zakres badawczy, wtaściwe źródta $i$ metody badawcze oraz środki dziatania ${ }^{5}$. Dobrym uzupełnieniem takiej definicji będzie wypowiedź Stanisława Kamińskiego. Specjalność, według tego autora, to trwale

Rozporzadzenie Ministra Nauki i Szkolnictwa Wyższego z dnia 8 sierpnia 2011 r. w sprawie obszarów wiedzy, dziedzin nauki i sztuki oraz dyscyplin naukowych i artystycznych, Dz. U.2011, nr 179, poz. 1065. Por.: Uchwata Centralnej Komisji do Spraw Stopni i Tytutów z dnia 24 października 2005 r. w sprawie określenia dziedzin nauki i dziedzin sztuki oraz dyscyplin naukowych i artystycznych, M. P. 2005, nr 79, poz. 1120. Zob. też: Uchwata Centralnej Komisji do Spraw Stopni i Tytutów z dnia 28 stycznia 2011 r. zmieniająca uchwate $w$ sprawie określenia dziedzin nauki i dziedzin sztuki oraz dyscyplin naukowych $i$ artystycznych z późniejsza zmianą, M. P. 2011, nr 14, poz. 149. Po dokonaniu w 2011 r. zmiany Ustawy $z$ dnia 14 marca 2003 r. o stopniach naukowych i tytule naukowym oraz o stopniach $i$ tytule $w$ zakresie sztuki (por.: Dz. U. 2003, nr 65, poz. 595 oraz Dz. U. 2011, nr 84, poz. 455), uprawnienie do określania dziedzin i dyscyplin naukowych oraz w zakresie sztuki przeszło z Centralnej Komisji do Spraw Stopni i Tytułów (dalej: CK) na rzecz Ministra Nauki i Szkolnictwa Wyższego. Zmianę taką oceniam negatywnie, ponieważ CK jest organem administracji publicznej wyłanianym w drodze wyboru dokonanego przez profesorów spośród profesorów posiadających dorobek naukowej w jednej z dziedzin nauki. Niewątpliwie ponad 230 uznanych i znanych reprezentantów polskiej nauki zasiadających w CK ma łącznie większe kompetencje do odpowiedniego podziału nauki na dziedziny i dyscypliny od Ministra Nauki i Szkolnictwa Wyższego, mimo że najczęściej zostaje nim także profesor.

5 A.J. Chodubski, Wstęp do badań politologicznych, Gdańsk 2013, s. 21. 
uksztaltowany zespót problematyki w ramach jakiejś dyscypliny naukowej ${ }^{6}$. Można dodać, że przy obecnych rozmiarach wiedzy i dzisiejszym podziale zadań w działaniach naukowych każdy badacz lub zespół badawczy stara się poruszać w granicach określonych jego specjalnością naukową. Od wskazania takiej specjalności najczęściej rozpoczyna się charakterystyka takiego badacza lub zespołu. W przypadku gdy uznaje on siebie za specjalistę w zakresie wielu specjalności, budzi to słuszne obawy o jego kompetencje. „Zespół problematyki” wyróżniający daną specjalność może niekiedy być przedmiotem zainteresowania dwóch lub większej liczny dyscyplin naukowych.

Natomiast dyscyplina to według Kamińskiego logicznie i treściowo zwarta część nauki, jaka - na danym szczeblu jej rozwoju i w określonych warunkach - może jeszcze skutecznie opanować w zakresie twórczych badań oraz dydaktyki jeden pracownik nauko$w y^{7}$. Z kolei Chodubski za dyscypliny uznaje gatęzie nauki wyodrębnione na podstawie kryteriów: przedmiotu nauki, ściśle określonego zakresu, wtaściwych źródet i metod badawczych oraz środków dziatania. Pewnym uszczegółowieniem tej definicji są słowa Benona Miśkiewicza stwierdzającego, iż przedmiot zainteresowania danej dyscypliny obejmuje określona czesść świata przyrodniczego lub spotecznego wyznaczonego do poznania ${ }^{9}$. W interesujący sposób tezy wymienionych autorów uzupełnia Tadeusz Kotarbiński, dla którego dyscypliną, nazywaną przezeń „nauką", jest wszelka catość godna tego, by byćprzedmiotem nauczania intelektualnego w szkolnictwie wyższym i dopiero w szkolnictwie wyższym, w charakterze odrębnej specjalności $i^{10}$.

W świetle powyższego politologia spełnia wszystkie kryteria pozwalające uznać ją za pełnoprawną dyscyplinę naukową. Po pierwsze, ma ona względnie określony przedmiot i zakres, którym jest badanie tego, co polityczne w życiu społecznym. Po drugie, politolodzy mają dostęp do źródeł, które potrafią gromadzić, selekcjonować, analizować oraz opracowywać na ich podstawie oceny i wnioski, wykorzystując w takim działaniu naukowe metody i techniki właściwe do prowadzenia badań na gruncie nauk społecznych, a także niektórych dyscyplin humanistycznych. Po trzecie, politologia ma coraz bogatsze środki działania. Składają się nań wydziały, instytuty, katedry i zakłady w szkołach wyższych, a także Instytut Nauk Politycznych PAN, wraz z całym zapleczem kadrowym, bibliotekami, redakcjami czasopism i urządzeniami, jakie do tych jednostek organizacyjnych należą. Po czwarte, politologia jest przedmiotem kształcenia na poziomie szkoły wyższej. Kierunek o takiej nazwie prowadzą prawie wszystkie uniwersytety, i to z powodzeniem, co potwierdzają oceny m.in. Polskiej Komisji Akredytacyjnej. Jednak rozwój wiedzy politologicznej sprawia, że występują coraz większe trudności ze spełnieniem warunków wyłonienia dyscypliny określonych przez Kamińskiego. Dlatego też wyodrębniły się już na bazie dotychczasowych specjalności politologii kolejne kierunki studiów (np. stosunki międzynarodowe, zarządzanie państwem,

$6 \quad$ S. Kamiński, Pojęcie nauki..., s. 231.

7 Tamże.

8 A.J. Chodubski, Wstęp do badań..., s. 21.

9 B. Miśkiewicz, Wstęp do badań historycznych, Poznań 1976, s. 48.

10 T. Kotarbiński, Studia z zakresu filozofii, etyki i nauk spotecznych, Wrocław 1970, s. 41. 
polityki publiczne). Pojawiły się także dążenia, tym razem ze strony nie urzędników, tylko niektórych zespołów badawczych, do przekształcenia politologicznych specjalności naukowych w odrębne dyscypliny ${ }^{11}$. Patrząc na dotychczasowy rozwój różnych nauk, takie działania mają wiele precedensów, ale biorąc pod uwagę dotychczasowy dorobek politologii w części dotyczącej specjalności, np. międzynarodowe stosunki polityczne, należy uznać je za zdecydowanie przedwczesne.

Dziedzina nauki to grupa dyscyplin, których przedmiotem zainteresowania jest podobna część świata przyrodniczego lub społecznego, jednak każda z nich podchodzi do badania tej części ze swojego punktu widzenia i w ten sposób przyczynia się do bardziej kompleksowego jej poznania. Dyscypliny operujące w tej samej dziedzinie łączy często wykorzystywanie podobnych metod i technik badawczych. Są jednak dziedziny, w ramach których nie ma dyscyplin naukowych. Najczęściej jest to efektem tego, że uprawiane na ich gruncie specjalności naukowe nie rozwinęły się na tyle, aby uzyskać status dyscypliny. W świetle obowiązującego dziś stanu prawnego dyscypliny nie zostały wyodrębnione w dziedzinie nauk teologicznych, weterynaryjnych, farmaceutycznych, nauk o zdrowiu i nauk o kulturze fizycznej. Wyszczególnianie dziedzin nauki jest także ważne w procesie kształcenia kadr naukowych. Przecież stopnie naukowe nadaje się w określonej dziedzinie nauki w zakresie jednej wchodzącej w jej skład dyscypliny, jeżeli taka została wyodrębniona. Natomiast tytułem naukowym jest tytuł profesora danej dziedziny nauki.

Z uwagi na tradycyjną już dla polskiej nauki dużą liczbę dziedzin w efekcie zmian dokonanych w $2011 \mathrm{r} .^{12}$, w celu pełniejszego uporządkowania nauk, kolejną jednostką podziału stał się obszar wiedzy naukowej. Do siedmiu obszarów nauk włączono łącznie dziewiętnaście dziedzin nauki, a w obszarze sztuki umiejscowiono cztery dziedziny sztuki. W obszarze nauk technicznych znalazła się tylko jedna dziedzina nauk technicznych, ale z dwudziestoma dwoma dyscyplinami. Do pozostałych obszarów nauk włączono dwie, trzy lub cztery dziedziny nauk. Do obszaru nauk humanistycznych włączono dziedzinę nauk humanistycznych i dziedzinę nauk teologicznych, zaś do obszaru nauk społecznych zaliczono dziedziny nauk społecznych, nauk ekonomicznych oraz nauk prawnych ${ }^{13}$.

Przechodząc do typologii dziedzin nauki i dyscyplin naukowych, należy zauważyć ich dużą różnorodnośćc ${ }^{14}$. Wybór kryterium podziału zawsze uzależniony jest od wyznaczenia celów takich działań. Chociaż klasyfikowanie dziedzin i dyscyplin naukowych nie jest celem niniejszego artykułu, to dla jasności dalszych wywodów, a przede wszystkim dla podjęcia próby umiejscowienia politologii w nauce, warto przywołać odnoszącą się do tego propozycje Kamińskiego, która zawiera się w schemacie 1. Autor ten za

11 Oczekiwania takie są widoczne zwłaszcza w działaniach części badaczy stosunków międzynarodowych.

12 Do 30 IX 2011 r. polska nauka podzielona była na - łącznie z dziedzinami sztuki - dwadzieścia jeden dziedzin. Po tej dacie wyszczególniono dwadzieścia trzy tego typu jednostki.

13 Zob. szerzej: Rozporzaddzenie Ministra Nauki i Szkolnictwa Wyższego z dnia 8 sierpnia 2011 r. w sprawie obszarów wiedzy...

14 Wiele z nich, mających wartość historyczną, jak i względnie nadal aktualnych, przedstawił Kamiński. Zob. szerzej: S. Kamiński, Pojęcie nauki..., s. 244-250. 
pierwsze kryterium podziału przyjął źródło wiedzy prowadzące do naukowego poznania. Mogą nim być prawdy objawione zaakceptowane w drodze wiary lub informacje pozyskane w drodze obserwacji, doświadczenia, analizowania otaczającej badacza rzeczywistości. Biorąc pod uwagę zakres naukowych poszukiwań, nauki można podzielić na filozofię, która szuka ostatecznych racji świata ujmowanego w kategoriach ontycznych, oraz nauki szczegółowe, szukające statych prawidtowości w aspekcie formalnej, ilościowej lub jakościowej strony obiektu badań. Te ostatnie dzielą się na nauki formalne mogące weryfikować hipotezy lub uzasadniać tezy bez odwoływania się do doświadczenia. Natomiast nauki realne (empiryczne) opierają się przede wszystkim na doświadczeniu $i[. .$.$] wnioskowaniu indukcyjnym. Ogólnie dzielą się one na nauki przyrodnicze i nauki$ humanistyczne (społeczne). Te pierwsze badają przyrodężywa i martwa, a precyzującpoznaja środowisko geograficzne oraz istoty żywe, w tym cztowieka, od strony fizycznej. Natomiast te drugie badają cztowieka spotecznego i wytwory jego kultury, szukajac typowości, która umożliwiataby interpretację zachowania się ludzi i natury ich wytworów $w^{15}$.

Schemat 1. Systematyka nauk według Stanisława Kamińskiego

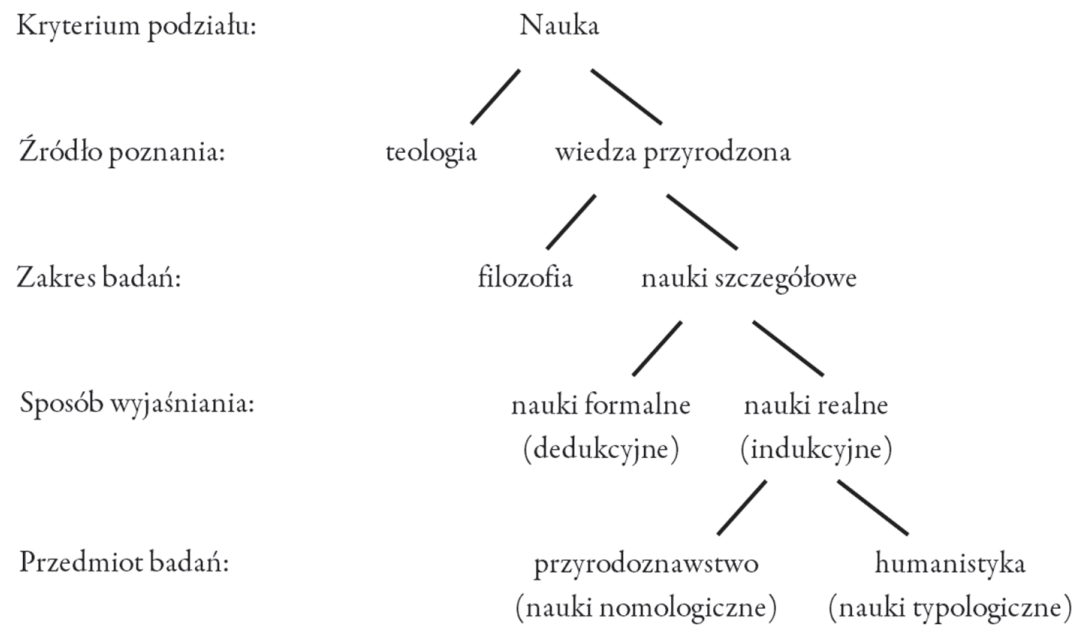

Źródło: opracowanie własne na podstawie: S. Kamiński, Pojęcie nauki i klasyfikacja nauk, wyd. 3 uzup., Lublin 1981, s. 249-250, Rozprawy Wydziatu Filozoficznego Towarzystwa Naukowego Katolickiego Uniwersytetu Lubelskiego, 35; tenże, Nauka i metoda. Pojęcie nauki i klasyfikacja nauk, Lublin 1992, s. 274, Pisma wybrane, 4. Prace Wydziatu Filozoficznego Towarzystwa Naukowego Katolickiego Uniwersytetu Lubelskiego, 54 .

Zaprezentowana systematyka jest oczywiście jedną z wielu możliwych, ale jej autorowi udało się w sposób „prosty i unifikujący” uwzględnić kryteria będące podstawą innych podziałów nauki. Pomimo upływu wielu lat od jej sporządzenia pozostaje ona aktualna w ogólnym zarysie, chociaż została ogłoszona po raz pierwszy w 1961 r. Inte-

15 Tamże, s. 249-250; B. Miśkiewicz, Wstęp do badań..., s. 49-50. 
resujące jest też to, że Kamiński dostrzegał dużą różnorodność nauk przyrodniczych oraz humanistycznych i podejmowal próby ich dzielenia. $\mathrm{Z}$ uwagi na cele niniejszych rozważań ważne było dostrzeżenie przezeń w obrębie humanistyki co najmniej trzech grup dyscyplin: o cztowieku $i$ spoteczeństwie, o wytworach kulturowych oraz o dziejach cztowieka spotecznego. Do pierwszej grupy autor ten zaliczył psychologie, etnologie, antropologie (kulturowa), nauki spoteczno-ekonomiczne. W drugiej grupie umieścił nauki prawnicze, o religii, o moralności, o sztuce i filologię, a w trzeciej nauki historyczne ${ }^{16}$. Można założyć, iż politologia, która w momencie ogłoszenia omówionej systematyki była w Polsce ciągle na początkowym etapie rozwoju ${ }^{17}$, zostałaby zaliczona do grupy nauk społeczno-ekonomicznych, gdyby tylko Kowalski wyliczył jej dyscypliny.

Zbliżone zróżnicowanie nauk humanistycznych dostrzegał także Miśkiewicz, który jednak tego typu nauki nazywał społecznymi, rzadziej - ale wymiennie - humanistycznymi ${ }^{18}$. Podobne stanowisko zajął Jan Such. Do najważniejszych nauk społecznych (humanistycznych) zaliczył on m.in. nauki polityczne ${ }^{19}$. Przy obecnym poziomie rozwoju nauki zamienne określanie tej samej grupy dyscyplin naukami humanistycznymi lub społecznymi jest coraz bardziej ryzykowne i słusznie pobudza środowiska badaczy do dyskusji oraz polemik.

Współcześnie najpełniejsze i najczęściej modernizowane klasyfikacje sporządza się na potrzeby administrowania nauką. Jest ona determinowana tym, że to w drodze administracyjnych decyzji m.in. tworzy się jednostki prowadzące badania naukowe, rozdziela się środki z budżetu państwa z przeznaczeniem na badania i kształcenie kadr naukowych, przyznaje się uprawnienia do nadawania stopni naukowych, nadaje się stopnie naukowe lub tytuł naukowy, uruchamia się w podstawowych jednostkach organizacyjnych szkół wyższych kształcenie na studiach drugiego i trzeciego stopnia, pod warunkiem prowadzenia badań naukowych w określonej dziedzinie wiedzy i dyscyplinie naukowej.

Interesujący podział polskiej nauki, właśnie na potrzeby rozdziału środków z budżetu państwa przeznaczonych na badania podstawowe, sporządziła Rada Narodowego Centrum Nauki. Wyszczególniła ona trzy działy nauk: „Nauki humanistyczne, społeczne i o sztuce”, „Nauki ścisłe i techniczne” oraz „Nauki o życiu”. W ich skład weszło łącznie dwadzieścia pięć paneli dziedzinowych ${ }^{20}$. Każdy podzielony jest naj-

16 S. Kamiński, Pojęcie nauki..., s. 267.

17 Tradycje badań i studiów politologicznych w Polsce ukazano m.in. w: B. Krauz-Mozer, P. Borowiec, P. Ścigaj, Kim jesteś, politologu? Historia i stan dyscypliny w Polsce, t. 1, Kraków 2011. Zob. też: B. Pasierb, Z tradycji polskiej nauki o polityce (czesśc 1). Nauka o polityce, kultura polityczna przetomu XIX i XX wieku, „Polityka i Społeczeństwo” 2005, nr 2, s. 104-119.

18 B. Miśkiewicz, Wstęp do badań..., s. 50.

19 J. Such, Klasyfikacja nauk, [w:] Filozofia a nauka. Zarys encyklopedyczny, Wrocław 1987, s. 303, Filozofia a Życie.

20 Interesujące jest to, że kompetencje Rady NCN zostały ograniczone ustawowo. Art. 18 ustawy o Narodowym Centrum Nauki pozwala jej na określanie maksymalnie trzydziestu dyscyplin lub grup dyscyplin, w ramach których będa ogtaszane i przeprowadzane konkursy na realizacje projektów badawczych. Zob. szerzej: Ustawa z dnia 30 kwietnia 2010 r. o Narodowym Centrum Nauki, tekst 
częściej na kilkanaście podpaneli. Panele i podpanele nazwano za pomocą nazw dyscyplin, grup dyscyplin, specjalności lub tematów badawczych. Problemy badawcze nauk o polityce przypisane zostały do panelu „HS5 Prawo, nauki o polityce, polityki publiczne”. W jego polu zainteresowań znalazły się przede wszystkim obszary badań właściwe dla wymienionych w nazwie dyscyplin (według NCN). Zastanawiająca jest - na tle innych dyscyplin - mała liczba podpaneli pozostających w zainteresowaniu politologów. W ich nazwach nie ma odzwierciedlenia wielu politologicznych specjalności (np. polityk szczegółowych) z wyjątkiem polityki społecznej i polityki regionalnej, chociaż wpisano je prawdopodobnie z myślą o nowej dyscyplinie, tj. naukach o polityce publicznej. Z lektury omawianego dokumentu wynika, iż do udziału w jego stanowieniu raczej nie zaproszono politologa. Na szczęście dla badaczy aplikujących o środki na badania naukowe ostatni podpanel nazywa się „Inne zagadnienia pokrewne”. Tak jest i w pozostałych panelach. W pewnym stopniu otwiera to możliwości ubiegania się o środki na badania interdyscyplinarne oraz prowadzące do tworzenia nowych specjalności naukowych.

Tabela 1. Panele i podpanele (zespoły) w dziale HS - nauki humanistyczne, społeczne i o sztuce według Rady Narodowego Centrum Nauki ${ }^{21}$

\begin{tabular}{|c|c|c|}
\hline Skrót & \multicolumn{1}{|c|}{$\begin{array}{c}\text { Nazwa panelu } \\
\text { HS1 }\end{array}$} & \multicolumn{1}{|c}{$\begin{array}{c}\text { Dundamentalne pytania } \\
\text { o naturę człowieka } \\
\text { i otaczającej go rzeczywistości }\end{array}$} \\
\hline HS1_1 & Historia filozofii (starożytnej, średniowiecznej, nowożytnej i współczesnej) i historia idei \\
\hline HS1_2 & Ontologia i metafizyka, ontologie szczegółowe & \multicolumn{1}{c}{$\begin{array}{c}\text { Filozofia, nauki o poznaniu, } \\
\text { religioznawstwo, teologia }\end{array}$} \\
\hline HS1_3 & Epistemologia (w tym: źródła poznania, kryteria prawdy, filozofia języka) \\
\hline HS1_4 & Logika, metodologia nauk, filozofia nauki \\
\hline HS1_5 & Filozofia człowieka, teorie osoby, filozofia kultury, filozofia społeczna \\
\hline HS1_6 & $\begin{array}{c}\text { Natura ludzkiego umysłu (w tym: ewolucja umysłu, bio-psychologiczne uwarunkowania } \\
\text { poznania, sztuczna inteligencja) }\end{array}$ \\
\hline HS1_7 & Etyka normatywna i opisowa, teoria moralności, bioetyka, etyka zawodowa \\
\hline HS1_8 & Estetyka (w tym: teorie piękna, język sztuki) \\
\hline HS1_9 & Teorie religii, historia religii, nauki religioznawcze \\
\hline HS1_10 & Religia i jej uwarunkowania: antropologiczne, kulturowe, socjo-psychologiczne \\
\hline HS1_11 & Język religii, sacrum, mit, symbolika religijna \\
\hline HS1_12 & Religie świata \\
\hline
\end{tabular}

jednolity stanowiący Załącznik do obwieszczenia Marszałka Sejmu Rzeczypospolitej Polskiej z dnia 26 maja 2015 r., Dz. U. 2015, poz. 839.

21 Pełny wykaz działów, paneli i podpaneli: Narodowe Centrum Nauki, Panele NCN, [online] https:// www.ncn.gov.pl/finansowanie-nauki/panele-ncn, 30 VII 2015. 


\begin{tabular}{|c|c|c|}
\hline Skrót & Nazwa panelu & Dziedziny \\
\hline HS1_13 & \multicolumn{2}{|l|}{ Teologia fundamentalna } \\
\hline HS1_14 & \multicolumn{2}{|c|}{ Teologia dogmatyczna, teologia biblijna, patrystyka } \\
\hline HS1_15 & \multicolumn{2}{|c|}{ Teologia moralna, teologia pastoralna, liturgika } \\
\hline HS1_16 & \multicolumn{2}{|l|}{ Inne zagadnienia pokrewne } \\
\hline HS2 & Kultura i twórczość kulturowa & $\begin{array}{l}\text { Literaturoznawstwo, językoznawstwo, } \\
\text { kulturoznawstwo, bibliotekoznawstwo, } \\
\text { nauki o sztuce, architektura }\end{array}$ \\
\hline HS2_1 & \multicolumn{2}{|c|}{$\begin{array}{l}\text { Historia literatury światowej (w tym: starożytnej, nowożytnej, współczesnej) i narodowej; } \\
\text { krytyka i interpretacja literacka }\end{array}$} \\
\hline HS2_2 & \multicolumn{2}{|c|}{$\begin{array}{l}\text { Teoria literatury, historia myśli literaturoznawczej, metody i kierunki badań literacko- } \\
\text {-kulturowych; antropologia literatury, komparatystyka i translatoryka literacko-kulturowa }\end{array}$} \\
\hline HS2_3 & \multicolumn{2}{|c|}{$\begin{array}{l}\text { Studia edytorsko-filologiczne, słownikowo-encyklopedyczne, } \\
\text { dokumentacyjno-bibliograficzne }\end{array}$} \\
\hline HS2_4 & \multicolumn{2}{|l|}{ Bibliologia i informatologia } \\
\hline HS2_5 & \multicolumn{2}{|c|}{$\begin{array}{l}\text { Językoznawstwo historyczne, porównawcze, typologiczne i współczesne; nauka o tekście } \\
\text { i gatunkach mowy }\end{array}$} \\
\hline HS2_6 & \multicolumn{2}{|c|}{ Językoznawstwo ogólne, teoria i metodologia badań językoznawczych } \\
\hline HS2_7 & \multicolumn{2}{|c|}{$\begin{array}{l}\text { Nauka o komunikacji i komunikowaniu, podstawy teoretyczne językoznawstwa } \\
\text { stosowanego }\end{array}$} \\
\hline HS2_8 & \multicolumn{2}{|c|}{ Historia i teoria sztuki, sztuki plastyczne, kultura wizualna } \\
\hline HS2_9 & \multicolumn{2}{|c|}{ Konserwatorstwo } \\
\hline HS2_10 & \multicolumn{2}{|l|}{ Muzealnictwo } \\
\hline HS2_11 & \multicolumn{2}{|c|}{ Muzyka (twórczość, wykonawstwo, teoria muzyki), muzykologia } \\
\hline HS2_12 & \multicolumn{2}{|c|}{ Teatrologia i sztuki performatywne (aktorstwo, taniec i in.) } \\
\hline HS2_13 & \multicolumn{2}{|l|}{ Filmoznawstwo i media audiowizualne } \\
\hline HS2_14 & \multicolumn{2}{|c|}{ Kulturoznawstwo (w tym: współczesne studia kulturowe i antropologiczno-kulturowe) } \\
\hline HS2_15 & \multicolumn{2}{|l|}{ Inne zagadnienia pokrewne } \\
\hline HS3 & Wiedza o przeszłości & $\begin{array}{l}\text { Historia, archeologia, etnologia, } \\
\text { antropologia kulturowa }\end{array}$ \\
\hline HS3_1 & $\begin{array}{l}\text { Historia epok dawnych (starożytna, śre } \\
\text { żytna i najnowsza (XIX-XX w.) }\end{array}$ & ieczna, wczesnonowożytna), historia nowo- \\
\hline HS3_2 & Historia społeczna & \\
\hline HS3_3 & Historia polityczna (w tym ustroju) & \\
\hline HS3_4 & Historia gospodarcza & \\
\hline HS3_5 & $\begin{array}{l}\text { Historia kultury (w tym: pamięć histor } \\
\text { studia kulturowe, zróżnicowanie kultur }\end{array}$ & historia kultury materialnej, historyczne \\
\hline
\end{tabular}




\begin{tabular}{|c|c|c|}
\hline Skrót & Nazwa panelu & Dziedziny \\
\hline HS3_6 & \multicolumn{2}{|c|}{ Historiografia, teoria i metodologia historii } \\
\hline HS3_7 & \multicolumn{2}{|l|}{ Archiwistyka } \\
\hline HS3_8 & \multicolumn{2}{|c|}{$\begin{array}{l}\text { Archeologia (w tym: archeologia Grecji i Rzymu, archeologia Egiptu i Nubii, archeolo- } \\
\text { gia Bliskiego Wschodu, archeologia Nowego Świata, archeologia pradziejowa, archeolo- } \\
\text { gia protohistoryczna, archeologia wczesnośredniowieczna, archeologia średniowieczna } \\
\text { i nowożytna) }\end{array}$} \\
\hline HS3_9 & \multicolumn{2}{|l|}{ Numizmatyka i epigrafika } \\
\hline HS3_10 & \multicolumn{2}{|l|}{ Papirologia } \\
\hline HS3_11 & \multicolumn{2}{|c|}{$\begin{array}{l}\text { Etnografia i antropologia kulturowa (w tym: opis kultur tradycyjnych, antropologia } \\
\text { magii, kultu i religii, zmiana kulturowa i procesy globalistyczne, antropologia zjawisk } \\
\text { społeczno-kulturowych, etnicznych i tożsamościowych) }\end{array}$} \\
\hline HS3_12 & \multicolumn{2}{|c|}{$\begin{array}{l}\text { Dziedzictwo kulturowe (w tym: inwentaryzacja pamiątek i zabytków kultury, aktywność } \\
\text { regionalistyczna) }\end{array}$} \\
\hline HS3_13 & \multicolumn{2}{|l|}{ Inne zagadnienia pokrewne } \\
\hline HS4 & Jednostka, instytucje, rynki & $\begin{array}{l}\text { Ekonomia, finanse, zarządzanie, } \\
\text { demografia, geografia społeczno- } \\
\text {-ekonomiczna, urbanistyka }\end{array}$ \\
\hline HS4_1 & \multicolumn{2}{|c|}{$\begin{array}{l}\text { Makroekonomia (w tym: równowaga ekonomiczna, wzrost gospodarczy, wahania ko- } \\
\text { niunkturalne w globalnej gospodarce, ekonomia pracy) }\end{array}$} \\
\hline HS4_2 & \multicolumn{2}{|c|}{ Mikroekonomia i ekonomia instytucjonalna } \\
\hline HS4_3 & \multicolumn{2}{|l|}{ Ekonometria i metody statystyczne } \\
\hline HS4_4 & \multicolumn{2}{|c|}{ Dynamika ludności i procesy demograficzne } \\
\hline HS4_5 & \multicolumn{2}{|c|}{ Zasoby i rozwój zrównoważony } \\
\hline HS4_6 & \multicolumn{2}{|c|}{ Rynki finansowe, finanse międzynarodowe, finanse publiczne } \\
\hline HS4_7 & \multicolumn{2}{|c|}{ Bankowość, finanse przedsiębiorstw, rachunkowość } \\
\hline HS4_8 & \multicolumn{2}{|c|}{ Ekonomia behawioralna, konsumpcja i zachowania konsumentów, marketing } \\
\hline HS4_9 & \multicolumn{2}{|c|}{$\begin{array}{l}\text { Zarządzanie organizacjami, zarządzanie strategiczne, koncepcje i metody zarządzania, } \\
\text { logistyka }\end{array}$} \\
\hline HS4_10 & \multicolumn{2}{|c|}{ Zarządzanie zasobami ludzkimi, zatrudnienie i płace } \\
\hline HS4_11 & \multicolumn{2}{|c|}{ Gospodarka publiczna, infrastruktura społeczna, administracja publiczna } \\
\hline HS4_12 & \multicolumn{2}{|c|}{ Warunki i jakość życia, dochody, ubóstwo } \\
\hline HS4_13 & \multicolumn{2}{|l|}{ Ekonomia międzynarodowa } \\
\hline HS4_14 & \multicolumn{2}{|l|}{ Geografia społeczno-ekonomiczna } \\
\hline HS4_15 & \multicolumn{2}{|l|}{ Urbanistyka, gospodarka przestrzenna } \\
\hline HS4_16 & \multicolumn{2}{|l|}{ Inne zagadnienia pokrewne } \\
\hline
\end{tabular}




\begin{tabular}{|c|c|c|}
\hline Skrót & Nazwa panelu & Dziedziny \\
\hline HS5 & $\begin{array}{l}\text { Prawo, nauki o polityce, } \\
\text { polityki publiczne }\end{array}$ & $\begin{array}{l}\text { Prawo, nauki o polityce, polityka regio- } \\
\text { nalna i społeczna }\end{array}$ \\
\hline HS5_1 & \multicolumn{2}{|c|}{ Teoria i filozofia prawa, historia prawa i myśli prawnej } \\
\hline HS5_2 & \multicolumn{2}{|c|}{ Prawo konstytucyjne, prawa człowieka, prawo i instytucje międzynarodowe } \\
\hline HS5_3 & \multicolumn{2}{|c|}{ Prawo publiczne i socjalne, nauka o administracji } \\
\hline HS5_4 & \multicolumn{2}{|l|}{ Prawo karne } \\
\hline HS5_5 & \multicolumn{2}{|l|}{ Prawo prywatne } \\
\hline HS5_6 & \multicolumn{2}{|l|}{ Teoria polityki i myśl polityczna } \\
\hline HS5_7 & \multicolumn{2}{|c|}{ Systemy i ruchy polityczne oraz stosunki międzynarodowe } \\
\hline HS5_8 & \multicolumn{2}{|l|}{ Polityka regionalna } \\
\hline HS5_9 & \multicolumn{2}{|c|}{$\begin{array}{l}\text { Polityka społeczna (w tym: polityka dotycząca ludności, zagadnienia zabezpieczenia spo- } \\
\text { łecznego, tzw. trzeci sektor, pomoc społeczna, gerontologia społeczna, governance i insty- } \\
\text { tucje dialogu społecznego) }\end{array}$} \\
\hline HS5_10 & \multicolumn{2}{|l|}{ Bezpieczeństwo i obronność } \\
\hline HS5_11 & \multicolumn{2}{|l|}{ Inne zagadnienia pokrewne } \\
\hline HS6 & Człowiek i życie społeczne & Psychologia, pedagogika, socjologia \\
\hline HS6_1 & \multicolumn{2}{|c|}{$\begin{array}{l}\text { Psychologia ogólna (w tym: procesów poznawczych, emocji, motywacji, osobowości, róż- } \\
\text { nic indywidualnych), psychologia eksperymentalna, psycholingwistyka }\end{array}$} \\
\hline HS6_2 & \multicolumn{2}{|c|}{ Psychologia społeczna, polityczna, środowiskowa i międzykulturowa } \\
\hline HS6_3 & \multicolumn{2}{|c|}{ Psychologia kliniczna, zdrowia, penitencjarna, rehabilitacji, neuropsychologia kliniczna } \\
\hline HS6_4 & \multicolumn{2}{|c|}{ Psychologia rozwoju, rodziny, wychowania i edukacji } \\
\hline HS6_5 & \multicolumn{2}{|c|}{$\begin{array}{l}\text { Psychologia ewolucyjna i porównawcza, genetyka zachowania, psychofizjologia, } \\
\text { neuropsychologia }\end{array}$} \\
\hline HS6_6 & \multicolumn{2}{|c|}{ Psychologia pracy, organizacji, ekonomiczna, reklamy i marketingu } \\
\hline HS6_7 & \multicolumn{2}{|c|}{ Historia myśli psychologicznej, metodologia, psychometria, diagnostyka psychologiczna } \\
\hline HS6_8 & \multicolumn{2}{|c|}{ Pedagogika ogólna, porównawcza i kultury } \\
\hline HS6_9 & \multicolumn{2}{|c|}{ Pedagogika społeczna i andragogika, profilaktyka społeczna i resocjalizacja } \\
\hline HS6_10 & \multicolumn{2}{|l|}{ Pedagogika specjalna } \\
\hline HS6_11 & \multicolumn{2}{|c|}{ Pedagogika edukacji (szkolna, szkoły wyższej) i dydaktyka } \\
\hline HS6_12 & \multicolumn{2}{|c|}{ Teoria i filozofia wychowania, historia oświaty i wychowania } \\
\hline HS6_13 & \multicolumn{2}{|c|}{ Socjologia teoretyczna, orientacje metodologiczne i warianty badań empirycznych } \\
\hline HS6_14 & \multicolumn{2}{|c|}{ Struktura i dynamika społeczna, zmiana środowiska i społeczeństwo } \\
\hline HS6_15 & \multicolumn{2}{|c|}{ Socjologia idei, władzy, norm, organizacji } \\
\hline
\end{tabular}




\begin{tabular}{|c|l|c|}
\hline Skrót & \multicolumn{1}{|c|}{ Nazwa panelu } & \multicolumn{1}{|c}{ Dziedziny } \\
\hline HS6_16 & $\begin{array}{l}\text { Socjologia kultury i komunikacji społecznej (w tym: medioznawstwo, dziennikarstwo, } \\
\text { komunikacja internetowa) }\end{array}$ \\
\hline HS6_17 & Socjologia gospodarki i edukacji \\
\hline HS6_18 & Socjologia rozwoju: wymiar lokalny, regionalny, makrospołeczny \\
\hline HS6_19 & Problemy społeczne i kierunki praktycznych działań socjologów \\
\hline HS6_20 & Przestrzeń publiczna \\
\hline HS6_21 & Inne zagadnienia pokrewne \\
\hline
\end{tabular}

Źródło: Panele NCN, NCN, [online] https://www.ncn.gov.pl/finansowanie-nauki/panele-ncn, 30 VII 2015.

Zawartość tab. 1 dowodzi też tego, że Rada NCN, ustalając panele, mniej kierowała się wskazaniami wynikającymi z Rozporządzenia Ministra Nauki i Szkolnictwa Wyższego z dnia 8 sierpnia 2011 r. w sprawie obszarów wiedzy, dziedzin nauki i sztuki oraz dyscyplin naukowych $i$ artystycznych, a bardziej chęcią wskazania problematyki przyszłych badań finansowanych z budżetu państwa oraz potrzebą powołania odpowiednich ekspertów do należytej oceny nadsyłanych wniosków. Na uwagę zasługuje też i to, że panele zaliczone do działu HS - Nauki humanistyczne, społeczne i o sztuce w zasadzie pokrywają cały obszar nauk humanistycznych, jaki został wyszczególniony w schemacie 1 . Może to świadczyć o dostrzeżeniu przez NCN pewnej jedności przedmiotowej i metodologicznej eksperymentalnych dyscyplin, które nie mogą być zaliczone do nauk przyrodniczych. Świadomość takiej jedności jest przydatna zwłaszcza przy prowadzeniu badań interdyscyplinarnych i korzystaniu z dorobku dyscyplin pokrewnych.

Najczęściej każda próba podziału nauki na dziedziny i dyscypliny lub jej modyfikacji rodzi jednak kontrowersje i pobudza, zwłaszcza bezpośrednio zainteresowanych zmianami, do dyskusji, a niekiedy nawet do zdecydowanych protestów ${ }^{22}$. Stało się tak m.in. po opublikowaniu wspomnianego rozporządzenia, kiedy to Komitet Nauk Politycznych PAN - wsparty uchwałami rad wielu jednostek organizacyjnych szkół wyższych prowadzących badania naukowe w zakresie dyscypliny nauki o polityce oraz kształcenie na kierunku politologia - uznał formalne wyodrębnienie nowej dyscypliny pod nazwą nauki o polityce publicznej za nieuzasadnione merytorycznie. Komitet wyraził także niezadowolenie z powodu podziału dziedziny nauk humanistycznych w kształcie obowiązującym do 30 września $2011 \mathrm{r}$. na odrębne dziedziny nauk społecznych i nauk humanistycznych, wskazując na przedmiotową i metodologiczną bliskość dyscyplin obecnie podzielonych między obie dziedziny.

Na podstawie obowiązującej do 30 września 2011 r. Uchwaty Centralnej Komisji do Spraw Stopni i Tytutów z dnia 24 października 2005 r. w sprawie określenia dzie-

22 Dzieje się tak z powodu postępującego zróżnicowania nauk i spowodowanego nim braku precyzyjnych kryteriów klasyfikacji. Piszą o tym m.in.: A.J. Chodubski, Wstęp do badań..., s. 20; S. Kamiński, Pojęcie nauki..., s. 227-234. 
dzin nauki i dziedzin sztuki oraz dyscyplin naukowych i artystycznych do dziedziny nauk humanistycznych zaliczono takie dyscypliny, jak: archeologia, bibliologia, etnologia, filozofia, historia, historia sztuki, językoznawstwo, kulturoznawstwo, literaturoznawstwo, nauki o bezpieczeństwie, nauki o obronności, nauki o polityce, nauki o poznaniu i komunikacji społecznej, nauki o sztuce, nauki o zarządzaniu, pedagogika, psychologia, religioznawstwo i socjologia ${ }^{23}$. Natomiast obecnie, na podstawie przywoływanego już kilka razy rozporządzenia, w dziedzinie nauk humanistycznej pozostały: archeologia, bibliologia i informatologia, etnologia, filozofia, historia, historia sztuki, językoznawstwo, kulturoznawstwo, literaturoznawstwo, nauki o sztuce, nauki o zarządzaniu, religioznawstwo oraz dodana została nowa dyscyplina pod nazwą nauki o rodzinie. Zaś w dziedzinie nauk społecznych umiejscowiono nauki o bezpieczeństwie, nauki o obronności, nauki o polityce, nauki o poznaniu i komunikacji społecznej, pedagogikę, psychologię, religioznawstwo i socjologię. Do tej dziedziny dodano także nowe dyscypliny, takie jak nauki o mediach i nauki o polityce publicznej ${ }^{24}$.

W celu udzielenia odpowiedzi na kluczowe pytanie o to, w jakiej dziedzinie powinny być umiejscowione nauki o polityce, należy podjąć jeszcze próbę wyjaśnienia istoty nauk humanistycznych i nauk społecznych. W takiej jednak sytuacji odwołania do ustaleń innych autorów (zwłaszcza polskich) mogą być tylko częściowo przydatne, ponieważ większość rozważań na temat humanistyki powstała w okresie przed dokonaniem formalnego jej podziału na odrębne dziedziny nauk.

Niewątpliwie, skoro nauki empiryczne, które nie mogą być zaliczone do nauk przyrodniczych (zob. schemat 1), łączy ogólny przedmiot badań i w znacznym stopniu metodologia ${ }^{25}$, to różnice nie mogą być zdecydowanie ostre. Zatem wydzielając w ich obszarze dziedziny nauk społecznych i nauk humanistycznych, szczególnie często przy omawianiu ich specyfiki należy powtarzać słowo „bardziej” lub „raczej”. Jest tak, ponieważ dziedziny te często różnią się tylko poziomem intensywności tej samej cechy. Biorąc to pod uwagę, proponuję przyjąć, że nauki społeczne to nauki o społeczeństwie, które wyróżnia m.in.:

1) większa metodologiczna więź z naukami przyrodniczymi. Kamiński, próbując usystematyzować humanistykę w znaczeniu wynikającym ze schematu 1, kierując się jej związkami z naukami przyrodniczymi, trafnie uznał, iż najbliżej takich nauk znajdują się dyscypliny o cztowieku $i$ spoteczeństwie ${ }^{26}$. W naukach społecznych w większym stopniu możliwe jest bowiem sprawdzanie hipotez w drodze eksperymentów i symulacji;

23 Uchwata Centralnej Komisji do Spraw Stopni i Tytutów z dnia 24 października 2005 r. w sprawie określenia dziedzin nauki i dziedzin sztuki...

24 O tej ostatniej zob. szerzej: J. Woźnicki, Nowa dyscyplina - „nauki o polityce publicznej” usytuowana $w$ dziedzinie nauk spotecznych, „Nauka” 2012, nr 1, s. 133-151.

25 Chociaż Such słusznie zauważa, że to od przedmiotu badań zależa $w$ dużym stopniu wszystkie pozostate kryteria. Natura i wtaściwości przedmiotu determinuja wybór metod i procedur badawczych zgodnych z ogólną problematyką nauki, jej zadaniami i celami. Zob. szerzej: J. Such, Klasyfikacja nauk..., s. 300.

26 S. Kamiński, Pojęcie nauki..., s. 267. 
2) możliwość prowadzenia na ich gruncie badań podstawowych, stosowanych, a nawet prac rozwojowych ${ }^{27}$. Przecież jednym z celów ogólnych badań, a w szczególności badań $w$ dziedzinie nauk spotecznych, jest dostarczenie wiedzy potrzebnej do podejmowania decyzji przez wtadze (na szczeblu centralnym, regionalnym lub lokalnym) lub przez przedsiębiorstwa przemystowe i handlowe ${ }^{28}$;

3) nastawienie na badanie raczej grup społecznych, współdziałania ich członków w celu uzyskania rezultatu, którego osiągnięcie integruje daną grupę, oraz poszukiwanie prawidłowości z tym współdziałaniem związanych;

4) skupienie się na poszukiwaniu prawidłowości w relacjach między współpracującymi lub rywalizującymi ze sobą grupami społecznymi;

5) stawianie akcentów na badanie teraźniejszości i formułowanie prognoz rozwoju życia społecznego.

Natomiast specyfiką dziedziny nauk humanistycznych jest m.in.:

1) mniejsza metodologiczna więź z naukami przyrodniczymi. Kamiński uznał, że nauki historyczne znajdują się najdalej od takich nauk i w porównaniu z naukami o społeczeństwie dostarczają materiatu do najbardziej kontrowersyjnych opini $i^{29}$. Przy weryfikowaniu hipotez w badaniach nad przedmiotem zainteresowania dyscyplin humanistycznych zdecydowanie mniejszą rolę odgrywają eksperymenty;

2) możliwość prowadzenia na ich gruncie badań podstawowych i ostatecznie stosowanych. Prowadzenie prac rozwojowych jest mało prawdopodobne;

3) nastawienie raczej na badanie jednostki, jej rozwoju duchowego i uwarunkowań społecznej aktywności takiej jednostki;

4) skupienie się na badaniu przede wszystkim wytworów ludzkiego umysłu (np. języka, sztuki, idei);

5) przywiązywanie większej wagi do ustalania faktów, wyjaśniania genezy teraźniejszości i poszukiwanie źródeł dzisiejszych zjawisk w przeszłości.

Biorąc pod uwagę powyższe, wypada przyjąć, że politologia wyraźnie w większym stopniu spełnia kryteria nauk społecznych niż humanistycznych. Ma ona taki status, ponieważ:

27 Istotę takich badań zdefiniowano na forum OBWE, uznając, że: badania podstawowe (basic research) to prace eksperymentalne lub teoretyczne podejmowane przede wszystkim w celu zdobycia nowej wiedzy na temat podtoża zjawisk $i$ obserwowalnych faktów bez nastawienia na konkretne zastosowanie lub wykorzystanie. Natomiast badania stosowane (applied research) to takize oryginalne prace badawcze podejmowane w celu zdobycia nowej wiedzy. Sa one jednak ukierunkowane przede wszystkim na osiagnięcie konkretnych celów praktycznych. Zaś prace rozwojowe (experimental development) to systematyczna praca opierajaça się na wiedzy uzyskanej w wyniku dziatalności badawczej oraz doświadczeń praktycznych i mająca na celu wytworzenie nowych materiatów, produktów lub urzadzeń, inicjowanie/instalowanie nowych lub znaczące udoskonalenie już istniejących procesów, systemów i ustug. Zob. szerzej: Organizacja Współpracy Gospodarczej i Rozwoju (dalej: OECD), Podręcznik Frascati. Proponowane procedury standardowe dla badań statystycznych w zakresie dziatalności badawczo-rozwojowej, 2002, s. 89-91, [online] http://www. oecdbookshop.org/get-it.php?REF=5KM7PFD7KSBR\&TYPE=browse, 30 VII 2015.

Tamże, s. 46.

29 S. Kamiński, Pojęcie nauki..., s. 267. 
a) w badaniach politologicznych możliwe jest sprawdzanie hipotez w drodze eksperymentów i symulacji, chociaż do ich rezultatów należy podchodzić z dużą rezerwą. Politolodzy, jak i przedstawiciele innych nauk społecznych, w odróżnieniu od badaczy operujących na gruncie nauk przyrodniczych, mają zdecydowanie większe problemy z ustaleniem obiektywnych wniosków. Przyczyną tego jest m.in. to, że uczestnicy takich badań mogą, kierując się nieartykułowanymi interesami i wartościami, nie mówić prawdy lub zachowywać się np. zgodnie z oczekiwaniami większości w grupie, aby nie stracić uznania $\mathrm{z}$ jej strony. W związku z tym przyjęte hipotezy powinny być weryfikowane za pomocą najlepiej wielu metod i technik badawczych ${ }^{30}$;

b) możliwe jest prowadzenie politologicznych badań podstawowych, stosowanych, a nawet prac rozwojowych. Chociaż politolodzy najczęściej zajmują się badaniami podstawowymi, to jednak możliwe jest prowadzenie przez nich także badań, których efekty będą wskazaniami odnoszącymi się bezpośrednio do praktyki. Natomiast rezultatem prac rozwojowych, uwzględniających wyniki badań podstawowych i stosowanych, może być zamówiony przez chociażby organ administracji publicznej program, model postępowania, który zostanie wdrożony do praktyki po sprawdzeniu jego kluczowych założeń na losowo lub w inny sposób wybranej grupie społecznej. Przyjmując np., że przedmiotem badania będzie polityka integracji cudzoziemców, to celem badań podstawowych nad tym zagadnieniem stanie się zbadanie np. polityki integracji cudzoziemców w wybranych państwach i jej ewolucji. Natomiast zadaniem badań stosowanych będzie zbadanie polityki integracji cudzoziemców w Polsce i określenie czynników determinujących jej wysoką skuteczność. Zaś celem prac rozwojowych może stać się opracowanie programu integracji cudzoziemców w Polsce i sprawdzenie jego funkcjonowania na przykładzie wybranej grupy cudzoziemców w danej wspólnocie lokalnej, szkole, zakładzie pracy lub ośrodku pobytowym dla uchodźców;

c) obiektem politologicznych badań jest polityka będąca m.in. działaniem społecznym. Jej cele określone interesami jednostki lub grupy mogą być urzeczywistniane tylko w relacjach z innymi jednostkami lub grupami. Jednak warunkiem skuteczności podejmowanych zabiegów jest często pozyskanie zaufania, poparcia lub zachęcenie do działania dużej grupy społecznej albo nakłonienie innej grupy do rezygnacji z aktywności;

d) bada ona to, co polityczne w życiu społecznym, w tym politykę. W związku z tym obejmuje swym zainteresowaniem - jak pisze Stephen D. Tansey - szeroki wachlarz sytuacji, w których ludzie kierujacy się odmiennymi interesami dziatają wspólnie dla osiagnięcia celów, które ich tącza, konkuruja ze sobą, gdy cele sa sprzeczne ${ }^{31}$;

30 O zagrożeniach w badaniach politologicznych piszą m.in.: J.B. Johnson, H.T. Reynolds, J.D. Mycoff, Metody badawcze w naukach politycznych, przeł. A. Kloskowska-Dudzińska, Warszawa 2010, s. 59-61. 
e) przedmiotem jej zainteresowania jest współczesne życie polityczne oraz procesy zapoczątkowane w przeszłości, pod warunkiem, że one ciągle trwają. Politolodzy jednak korzystają z efektów badań historyków, ponieważ pozwalają one ukazać i wyjaśnić genezę instytucji oraz zjawisk zachodzących aktualnie w politycznej sferze życia społecznego, a także prognozować jego rozwój. Jednak najnowsza historia polityczna, która traktuje o sprawach już minionych (zakończonych), jest częścią historii, a nie politologii.

Ponieważ do dziedziny nauk powinny być włączane dyscypliny pokrewne, to trafność decyzji o zaliczeniu nauk o polityce do dziedziny nauk społecznych można też zweryfikować, określając relacje pomiędzy politologią a innymi dyscyplinami nauk społecznych oraz dyscyplinami nauk humanistycznych. Analizując te relacje, można dostrzec bezpośrednie związki ze wszystkimi dyscyplinami dziedziny nauk społecznych poprzez częściowo wspólny przedmiot badań i możliwość wykorzystywania także podobnych narzędzi badawczych. Dotyczy to też niektórych dyscyplin zaliczonych do pozostałych dziedzin nauk społecznych, tj. ekonomii i nauk o zarządzaniu w dziedzinie nauk ekonomicznych, a także prawa oraz nauk o administracji w dziedzinie nauk prawnych.

Natomiast relacje z dyscyplinami nauk humanistycznych są zróżnicowane. Dla politologów najbardziej przydatna jest wiedza o polityce dostarczana przez filozofię i historię. Jest tak, ponieważ dyscypliny te na tyle rozwinęły zainteresowanie polityką, że wykształciły się już ich subdyscypliny, tj. filozofia polityki w filozofii i historia polityczna w historii. Ustalenia pozostałych dyscyplin humanistycznych w badaniach politologicznych odgrywają mniejszą rolę z dwóch powodów. Pierwszym z nich jest zdecydowanie mniejsze ich zainteresowanie badaniem politycznych uwarunkowań rozwoju sztuki, kultury lub języka. Natomiast drugim jest to, że politologia ciągle poszerza obszar swego zainteresowania oraz rozwija się m.in. pod względem kadrowym, co pozwala dopiero w miarę tego rozwoju na podejmowanie nowych tematów badawczych. W rezultacie obecnie zwiększa się zainteresowanie politologów rolą np. języka, muzyki i innych sztuk w działaniach politycznych, co potwierdzają opublikowane efekty badań w postaci książek i artykułów.

Chociaż niektóre nauki mają podobnie nazywające się subdyscypliny - np. nauka o polityce bezpieczeństwa wewnętrznego ma taki status w politologii i jednocześnie tak nazywająca się subdyscyplina jest częścią nauk o bezpieczeństwie, zaś nauka o polityce gospodarczej jest subdyscypliną ekonomii i tak samo nazywa się ważny element nauk o polityce - to jednak nie oznacza, że są to wspólne subdyscypliny tych nauk. Wspólny jest tylko ich przedmiot badań. Politykę gospodarczą badają ekonomia, nauki o polityce i nauki o polityce publicznej, ale każda z tych nauk robi to ze swego punktu widzenia, kierując się celami, do których realizacji została powołana. To, iż dwie lub nawet trzy dyscypliny za przedmiot badań wybrały ten sam fragment życia politycznego, nie musi oznaczać konkurencji między nimi. Wprost przeciwnie, takie badania są tylko różnymi drogami prowadzącymi do poszerzenia naukowego poznania polityki i polityczności ${ }^{32}$.

Należy też zauważyć, że dla innych nauk społecznych i humanistycznych efekty politologicznych badań także mają (powinny mieć) duże znaczenie. Dyscyplina ta do-

32 A. Heywood, Politologia, przeł. B. Maliszewska i in., Warszawa 2006, s. 19. 
starcza przecież m.in. wiedzy o naturze tego, co polityczne, o uwarunkowaniach życia politycznego oraz mechanizmach i instrumentach walki politycznej. Wykorzystanie dorobku politologii przez inne dyscypliny pozwala zwiększyć efektywność prowadzonych na ich gruncie badań, obniżyć ich koszty, a przede wszystkim zwiększyć trafność formulowanych tez i prognoz.

Potwierdzeniem tezy, że politologia jest ważnym elementem nauk społecznych, są także niektóre klasyfikacje międzynarodowe. Jedną z nich jest podział nauk powstały pod patronatem Sekretariatu Generalnego Organizacji Współpracy Gospodarczej i Rozwoju, który w istotnym fragmencie zaprezentowano w tab. 2. Ostatnią jego wersję opublikowano w 2006 r. Jest ona rezultatem negocjacji w gronie ekspertów tej organizacji oraz UNESCO i Eurostatu, tj. Europejskiego Urzędu Statystycznego, który jest jednostką organizacyjną Komisji Europejskiej UE z siedzibą w Luksemburgu. Klasyfikację sporządzono w celu prowadzenia porównawczych badań statystycznych działalności naukowej w państwach członkowskich oraz ich polityki naukowej. Potrzeba wypracowania omawianej systematyki determinowana była także intensyfikacją międzynarodowej współpracy krajowych ośrodków naukowych i badaczy, a także działalnością coraz częściej powoływanych ponadnarodowych instytucji i zespołów badawczych. Uznanej na forum międzynarodowym klasyfikacji nauk potrzebują również organizacje i instytucje przyznające środki na działalność naukową. Bardzo dużą rolę odgrywa w tym Unia Europejska, która przeznaczyła znaczne środki na realizację programu badań i innowacji „Horyzont 2020”. Z uwagi na autorytet wymienionych organizacji zaproponowany podział uznawany jest także w wielu państwach spoza OECD ${ }^{33}$.

Analizując doświadczenia różnych państw w prowadzeniu polityki naukowej, niewątpliwie klasyfikacja zaprezentowana w tab. 2 jest efektem kompromisu uwzględniającego ich tradycje oraz aktualne oczekiwania naukowców, a także instytucji powołanych do administrowania nauką ${ }^{34}$. Jej zaletą jest otwartość na rozwój, którego rezultatem będą zapewne kolejne dyscypliny. W każdej dziedzinie możliwe jest dodanie następnej tego typu jednostki podziału w punkcie „inne nauki.... Z uwagi na cele niniejszych rozważań istotne jest to, że omawiana klasyfikacja dzieli dyscypliny na sześć dziedzin, w tym wyróżnia nauki społeczne i nauki humanistyczne, jednoznacznie zaliczając nauki polityczne do tej pierwszej dziedziny nauk.

Niewątpliwie jednym z celów urzędowej modyfikacji podziału polskiej nauki dokonanej przez ministra nauki i szkolnictwa wyższego w $2011 \mathrm{r}$. było dostosowanie tego podziału do standardów uznawanych na forum międzynarodowym. Dlatego też rozdzielono humanistykę na dziedziny nauk społecznych i nauk humanistycznych. Chcąc jednak zachować wyodrębnioną znacznie wcześniej dużą liczbę dziedzin, tradycyjną już dla polskich badaczy, zastosowano kolejną jednostkę podziału, jaką stał się obszar wiedzy. Dzięki pogrupowaniu dziedzin na obszary nauk obecnie obowiązująca w Pol-

OECD, Podręczik Frascati..., s. 3.

34 D. Maciejko, Klasyfikacja dziedzin i dyscyplin naukowych w badaniach statystycznych, Ministerstwo Nauki i Szkolnictwa Wyższego, [online] http://www.nauka.gov.pl/polska-nauka/klasyfikacja-dzie dzin-i-dyscyplin-naukowych-w-badaniach-statystycznych,archiwum,1,akcja,pdf.html, 8 VIII 2015. 
sce klasyfikacja jest bardzo podobna do jej odpowiedniczki ustalonej na forum OECD. Pomijając szczegóły, można zauważyć, iż większa liczba obszarów wiedzy (8) w porównaniu z sześcioma dziedzinami nauk określonymi przez OECD jest rezultatem podziału nauk przyrodniczych na „obszar nauk ścisłych” i „obszar nauk przyrodniczych” oraz nauk humanistycznych na „obszar nauk humanistycznych” i „obszar sztuki”. Uwzględniając te różnice, można przyjąć, że obszary wiedzy grupujące dziedziny nauki w Polsce odpowiadają dziedzinom nauk w klasyfikacji OECD.

Tabela 2. Klasyfikacja dziedzin nauki i techniki według OECD

\begin{tabular}{|c|c|}
\hline Dziedziny nauki & Dyscypliny* \\
\hline 1. Nauki przyrodnicze & $\begin{array}{l}\text { 1.1. Matematyka } \\
\text { 1.2. Nauki o komputerach i informatyka } \\
\text { 1.3. Nauki fizyczne } \\
\text { 1.4. Nauki chemiczne } \\
\text { 1.5. Nauki o ziemi i o środowisku } \\
\text { 1.6. Nauki biologiczne (nauki medyczne należą do } 3 \text {, a rolnicze do } 4 \text { ) } \\
\text { 1.7. Inne nauki przyrodnicze }\end{array}$ \\
\hline $\begin{array}{l}\text { 2. Nauki inżynieryjne } \\
\text { i techniczne }\end{array}$ & $\begin{array}{l}\text { 2.1. Inżynieria lądowa } \\
\text { 2.2. Elektrotechnika, elektronika, inżyniera informatyczna } \\
\text { 2.3. Inżynieria mechaniczna } \\
\text { 2.4. Inżynieria chemiczna } \\
\text { 2.5. Inżynieria materiałowa } \\
\text { 2.6. Inżynieria medyczna } \\
\text { 2.7. Inżynieria środowiska } \\
\text { 2.8. Biotechnologia środowiskowa } \\
\text { 2.9. Biotechnologia przemysłowa } \\
\text { 2.10. Nanotechnologia } \\
\text { 2.11. Inne nauki inżynieryjne i technologie }\end{array}$ \\
\hline $\begin{array}{l}\text { 3. Nauki medyczne } \\
\text { i nauki o zdrowiu }\end{array}$ & $\begin{array}{l}\text { 3.1. Medycyna ogólna } \\
\text { 3.2. Medycyna kliniczna } \\
\text { 3.3. Nauka o zdrowiu } \\
\text { 3.4. Biotechnologia medyczna } \\
\text { 3.5. Inne nauki medyczne }\end{array}$ \\
\hline 4. Nauki rolnicze & $\begin{array}{l}\text { 4.1. Rolnictwo, leśnictwo i rybolówstwo } \\
\text { 4.2. Nauka o zwierzętach i mleczarstwie } \\
\text { 4.3. Nauki weterynaryjne } \\
\text { 4.4. Biotechnologia rolnicza } \\
\text { 4.5. Inne nauki rolnicze }\end{array}$ \\
\hline
\end{tabular}

* Podział dyscyplin na subdyscypliny przedstawiono tylko dla nauk społecznych i humanistycznych. Zob. szerzej: OECD, Podręcznik Frascati..., s. 303-310. 
Dziedziny nauki

5. Nauki społeczne

\section{Dyscypliny*}

\subsection{Psychologia}

- Psychologia (w tym: relacje człowiek-maszyna)

- Psychologia specjalistyczna (w tym: terapia w zakresie uczenia się, mowy, słyszenia, widzenia oraz innych upośledzeń fizycznych i umysłowych)

\subsection{Ekonomia i biznes}

- Ekonomia, ekonometria

- Stosunki przemysłowe

- Biznes i zarządzanie

\subsection{Pedagogika}

- Pedagogika ogólna (w tym: szkolenia, pedagogika, dydaktyka)

- Pedagogika specjalistyczna (praca z osobami uzdolnionymi, z osobami mającymi trudności w uczeniu się)

\subsection{Socjologia}

- Socjologia

- Demografia

- Antropologia, etnologia

- Problematyka społeczna (feminologia i badania nad płcią kulturową, problemy społeczne, nauka o rodzinie, praca socjalna)

\subsection{Prawo}

- Prawo, kryminologia, penologia

\subsection{Nauki polityczne}

- Nauki polityczne

- Administracja publiczna

- Teoria organizacji

\subsection{Geografia społeczna i gospodarcza}

- Nauka o środowisku (aspekty społeczne)

- Geografia kulturowa i gospodarcza

- Urbanistyka (planowanie i rozwój przestrzenny)

- Planowanie transportu i społeczne aspekty transportu (inżynieria transportu należy do 2.1)

\subsection{Media i komunikowanie}

- Dziennikarstwo

- Nauka o informacji (aspekty społeczne)

- Bibliotekoznawstwo

- Media i komunikowanie społeczno-kulturalne

\subsection{Inne nauki społeczne}

- Nauki społeczne interdyscyplinarne

- Inne nauki społeczne 


\begin{tabular}{|c|c|}
\hline Dziedziny nauki & Dyscypliny* \\
\hline 6. Nauki humanistyczne & $\begin{array}{l}\text { 6.1. Historia i archeologia } \\
\text { - Historia (historia nauki i techniki należy do 6.3, historia kon- } \\
\text { kretnych nauk należy do odpowiednich nauk) } \\
\text { - Archeologia } \\
\text { 6.2. Języki i literatura } \\
\text { - Językoznawstwo ogólne } \\
\text { - Językoznawstwo poszczególnych języków } \\
\text { - Literaturoznawstwo ogólne } \\
\text { - Teoria literatury } \\
\text { - Literatury w poszczególnych językach } \\
\text { - Lingwistyka } \\
\text { 6.3. Filozofia, etyka i religia } \\
\text { - Filozofia, historia i filozofia nauki i techniki } \\
\text { - Etyka (z wyjątkiem etyki dotyczącej poszczególnych dziedzin) } \\
\text { - Teologia } \\
\text { - Religioznawstwo } \\
\text { 6.4. Sztuka (sztuka, historia sztuki, sztuki sceniczne, muzyka) } \\
\text { - Sztuka, historia sztuki } \\
\text { - Projektowanie architektoniczne } \\
\text { - Nauka o sztukach scenicznych (muzykologia, teatrologia, } \\
\text { dramaturgia) } \\
\text { - Folklorystyka } \\
\text { - Nauka o filmie, radiu i telewizji } \\
\text { 6.5. Inne nauki humanistyczne }\end{array}$ \\
\hline
\end{tabular}

Źródło: Organizacja Współpracy Gospodarczej i Rozwoju, Podręcznik Frascati. Proponowane procedury standardowe dla badań statystycznych w zakresie dziatalności badawczo-rozwojowej, 2002, s. 303-310, [online] http://www.oecdbookshop.org/get-it.php?REF=5KM7PFD7KSBR\&TYPE=browse, 30 VII 2015.

Pomimo podziałów konstruowanych na różne potrzeby należy jednak pamiętać, że nauka jest też pewną jednością, której fundamentem jest najbardziej ogólny cel jej istnienia i funkcjonowania oraz metoda postępowania. Celem tym jest poznanie świata, praw oraz prawideł regulujących jego organizację i funkcjonowanie. Do realizacji takiego celu przyczyniają się także dyscypliny nauk humanistycznych i nauk społecznych, w tym politologia. Dyscypliny wchodzące w skład takich dziedzin według Tadeusza Kotarbińskiego [...] przygotowują organizacje stosunków międzyludzkich $i$ ksztattują najogólniejsze dyspozycje cztowieka jako istoty gospodarującej i wspótgospodarującej. W związku z tym nauki tego typu nie są czymś odrębnym od produkcji, ponieważ są jej faza przygotowawcza, jako jej część sktadowa $a^{35}$. Niestety, niekiedy nie chcą tego dostrzec przedstawiciele m.in. nauk przyrodniczych, technicznych, medycznych i rolni-

35 T. Kotarbiński, Studia z zakresu filozofii..., s. 48. 
czych, uzasadniając „wyższość” uprawianych dyscyplin nad dyscyplinami humanistycznymi i społecznymi tym, że te ostatnie rzekomo w minimalnym stopniu przyczyniają się do rozwoju gospodarki i determinowanej jej stanem jakości życia. Takie twierdzenie, chociaż nieuzasadnione, nie byłyby większym problemem, gdyby pomijali je decydenci rozdzielający środki na badania naukowe. O niedocenianiu nauk humanistycznych i społecznych świadczyć mogą dane zawarte w tab. 3 .

Tabela 3. Wysokość przyznanego finansowania w panelach dyscyplin w konkursach Narodowego

Centrum Nauki rozstrzygniętych w 2014 r. z wyłączeniem konkursów Etiuda 2, Fuga 3 i Symfonia 2

\begin{tabular}{|l|c|c|c|c|}
\hline \multicolumn{1}{|c|}{ Panel dyscyplin } & \multicolumn{2}{|c|}{$\begin{array}{c}\text { Wnioski zakwalifikowane } \\
\text { do finansowania }\end{array}$} & $\begin{array}{c}\text { Wartość wniosków } \\
\text { zakwalifikowana } \\
\text { do finansowania }\end{array}$ \\
\hline & Liczba & $\%$ & w mln zł & $\%$ \\
\hline $\begin{array}{l}\text { Nauki humanistyczne, społeczne } \\
\text { i o sztuce }\end{array}$ & 543 & 32,79 & 122,5 & 17,66 \\
\hline Nauki o życiu & 493 & 29,77 & 267,1 & 38,50 \\
\hline Nauki ścisłe i techniczne & 620 & 37,44 & 304,2 & 43,84 \\
\hline Razem & 1656 & 100 & 693,8 & 100 \\
\hline
\end{tabular}

Żródło: Narodowe Centrum Nauki, Statystyki konkursów 2014, [online] https://www.ncn.gov.pl/sites/ default/files/pliki/statystyki/NCN_statystyki_2014_pl.pdf, 30 VII 2015.

Przechodząc do podsumowania, należy zauważyć, iż wspomniane wyżej argumenty leżące u podstaw zaprezentowanych klasyfikacji potwierdzają status politologii jako dyscypliny należącej do nauk społecznych. Jednak klasyfikacje te będą nadal modyfikowane, a nawet zmieniane. Czynnikiem to determinującym już jest i będzie w coraz większym stopniu interdyscyplinarność w badaniach naukowych. Okazuje się, że jej wielka zastuga jest tworzenie nieograniczonych możliwości generowania nowej wiedzy. Wspótczesna wiedza, z jej nieustannymi zmianami powiąań pomiędzy polami (obszarami) badań i jej statym wzajemnym oddziatywaniem na siebie różnych specjalności, z trudem rozwija się w ramach tradycyjnych dyscyplin, budowanych za murami specjalizacji $i$ akademickości ${ }^{36}$. Kryteriami podziału w nauce będą w rosnącym wymiarze tematy badań, wokół których skupiać się będą badacze z różnych nauk. Istotną rolę w omawianym procesie już odgrywają wyszukiwarki internetowe, które za pomocą słów kluczowych, a nie nazw dyscyplin pozwalają dotrzeć do wiedzy na dany temat wypracowanej na gruncie różnych dyscyplin. Jesteśmy zatem zapewne na progu epoki, w której najlepsze rezultaty naukowego poznania będą się rodzić na gruncie interdyscyplin, multidyscyplin i transdyscyplin ${ }^{37}$.

36 B.R. Kuc, O nauce, dyscyplinach naukowych i kierunkach ich rozwoju, Wydawnictwo PTM, [online] http://wydawnictwoptm.pl/content/8-artykuly-naukowe, 11 VIII 2015.

37 Tamże. Interesujące wnioski na temat przyszłości nauk społecznych zawiera m.in. raport Komisji Gulbenkiana na Rzecz Restrukturyzacji Nauk Społecznych Otwórzmy nauki spoteczne. Zob. szerzej: Wyzwania wobec nauk spotecznych u progu XXI wieku, oprac. A. Flis, przeł. B. Lessaer, Kraków 1999. 
Należy także zauważyć, że w warunkach wolności badań naukowych raczej nikt nie może stwierdzić, iż klasyfikacja dyscyplin naukowych stanowi istotną przeszkodę w realizacji zamierzeń badawczych. Przeszkodą może być tylko brak środków finansowych, brak dostępu do aparatury badawczej lub zgody przełożonych na realizację danego zamierzenia w zakładzie, katedrze lub instytucie. Przeszkody te można jednak zniwelować, finansując badania ze środków własnych lub od zewnętrznego sponsora. Badania można też prowadzić $\mathrm{w}$ innym ośrodku krajowym lub zagranicznym. Jednak warunkiem tego jest zaproponowanie innowacyjnego problemu badawczego. Wyjątkiem są jednak naukowe przedsięwzięcia, których rezultaty mają stać się podstawą wniosku o stopień naukowy. W takiej sytuacji muszą one dotyczyć obszaru zainteresowania jednej z urzędowo uznanych dyscyplin naukowych.

\section{BIBLIOGRAFIA}

Chodubski A.J., Wstęp do badań politologicznych, Gdańsk 2013.

Heywood A., Politologia, przel. B. Maliszewska i in., Warszawa 2006.

Johnson J.B., Reynolds H.T., Mycoff J.D., Metody badawcze w naukach politycznych, przeł. A. Kloskowska-Dudzińska, Warszawa 2010.

Kamiński S., Nauka i metoda. Pojęcie nauki i klasyfikacja nauk, Lublin 1992, Pisma wybrane,

4. Prace Wydziatu Filozoficznego Towarzystwa Naukowego Katolickiego Uniwersytetu Lubelskiego, 54 .

Kamiński S., Pojęcie nauki i klasyfikacja nauk, wyd. 3 uzup., Lublin 1981, Rozprawy Wydziatu Filozoficznego Towarzystwa Naukowego Katolickiego Uniwersytetu Lubelskiego, 35.

Kotarbiński T., Studia z zakresu filozofii, etyki i nauk spotecznych, Wrocław 1970.

Krauz-Mozer B., Borowiec P., Ścigaj P., Kim jesteś, politologu? Historia i stan dyscypliny w Polsce, t. 1, Kraków 2011.

Kuc B.R., O nauce, dyscyplinach naukowych i kierunkach ich rozwoju, Wydawnictwo PTM, [online] http://wydawnictwoptm.pl/content/8-artykuly-naukowe.

Maciejko D., Klasyfikacja dziedzin i dyscyplin naukowych w badaniach statystycznych, Ministerstwo Nauki i Szkolnictwa Wyższego, [online] http://www.nauka.gov.pl/polska-nauka/ klasyfikacja-dziedzin-i-dyscyplin-naukowych-w-badaniach-statystycznych,archiwum, 1,akc ja,pdf.html.

Marcos A., Filozofia nauki. Nowe wymiary, przel. i red. P. Roszak, Toruń 2012.

Miśkiewicz B., Wstęp do badań historycznych, Poznań 1976.

Narodowe Centrum Nauki, Panele NCN, [online] https://www.ncn.gov.pl/finansowanie-nauki/panele-ncn.

Narodowe Centrum Nauki, Statystyki konkursów 2014, [online] https://www.ncn.gov.pl/sites/ default/files/pliki/statystyki/NCN_statystyki_2014_pl.pdf.

Organizacja Współpracy Gospodarczej i Rozwoju, Podręcznik Frascati. Proponowane procedury standardowe dla badań statystycznych w zakresie dziatalności badawczo-rozwojowej, 2002, [online] http://www.oecdbookshop.org/get-it.php?REF=5KM7PFD7KSBR\&TYPE= browse. 
Pasierb B., Z tradycji polskiej nauki o polityce (czesść 1). Nauka o polityce, kultura polityczna przetomu XIX i XX wieku, „Polityka i Społeczeństwo” 2005, nr 2.

Reale G., Historia filozofii starożytnej, t. 2: Platon i Arystoteles, przeł. E.I. Zieliński, Lublin 2001. Sobczyńska D., Między nauka a twórczościq artystyczną, [w:] Wspótczesna filozofia nauk, red. T. Buksiński, Poznań 1991, Filozofia i Logika, 60.

Such J., Klasyfikacja nauk, [w:] Filozofia a nauka. Zarys encyklopedyczny, Wroctaw 1987, Filozofia a Życie.

Tansey S.D., Nauki polityczne, przeł. J. Gilewicz, Poznań 1997.

Woźnicki J., Nowa dyscyplina - „nauki o polityce publicznej” usytuowana w dziedzinie nauk spotecznych, „Nauka” 2012, nr 1.

Wyzwania wobec nauk spotecznych u progu XXI wieku, oprac. A. Flis, przeł. B. Lessaer, Kraków 1999.

Dr hab. Tadeusz WALLAS, prof. UAM - doktor habilitowany nauk o polityce, zatrudniony na stanowisku profesora nadzwyczajnego na Wydziale Nauk Politycznych i Dziennikarstwa Uniwersytetu im. Adama Mickiewicza w Poznaniu. Naukowo interesuje się współczesnymi systemami politycznymi, współczesną kulturą polityczną oraz politycznymi aspektami globalizacji i integracji europejskiej. Jest wiceprzewodniczącym Komitetu Nauk Politycznych PAN oraz wiceprzewodniczącym Zarządu Głównego Polskiego Towarzystwa Nauk Politycznych. 